\title{
Digital transformation of the energy industry in the Russian economy
}

\author{
Gulnaz Galeeva ${ }^{1, *}$ \\ ${ }^{1}$ Kazan Federal University, Kazan, Russia
}

\begin{abstract}
This study analyzes the reasons, factors and prerequisites for the development of digitalization processes in the energy industry in Russia. An overview of the Digitalization Strategy of the Russian industry, its priority goals and objectives is presented. Based on the analysis of the Energy Strategy of Russia until 2035, the main problems and threats to the development of the industry are highlighted. Among the tasks of digitalization of the energy industry in Russia, priorities are outlined: working with big data, increasing the efficiency of asset use, transforming the model of interaction with customers, optimizing the system of electricity management and distribution. The article, based on the data of the Ministry of Energy of the Russian Federation and information posted on the official websites of energy companies, collected and analyzed material on the role of digital technologies and the dynamics of their implementation in the energy complex of Russia. Energy policy priorities vary from country to country, but the role of digital technology is widely recognized. In conclusion, conclusions are drawn about the expected effects of the introduction of digital technologies in the field of operational safety of energy infrastructure facilities, an increase in the technical level of energy systems and a reduction in losses.
\end{abstract}

\section{Introduction}

Russia is a net exporter of all types of energy resources, except for uranium, and consistently ranks 1 st in the world in gas exports, 2nd in oil exports and 3rd in coal exports. Russia provides $16 \%$ of the world energy trade, exporting about half of the primary energy produced (in 2018, 708 Mtoe with an energy production of about 1,440 Mtoe). In the future, Russia will retain its position as one of the largest suppliers of energy resources. to world markets. According to the Energy Strategy of the Russian Federation for the period up to 2035 (hereinafter referred to as the Energy Strategy), the total volume of energy exports by 2035 will increase by $1.15-1.46$ times and will amount to approximately $800-1000$ million tons of oil equivalent. The share of natural gas, as the cleanest hydrocarbon energy source, in the total volume of primary energy consumption is planned to increase from $51.9 \%$ in 2018 to $53-55 \%$ by 2035 , and the share of non-carbon energy sources (nuclear energy, hydropower, etc. RES) - from $14.8 \%$ to $16.5 \%$.

The share of coal in domestic consumption has been declining for a long time. If in 2000 it was $19.9 \%$, then by 2018 it dropped to $12.3 \%$, and will remain approximately at the same level until $2035[1,2]$.

Among the largest economies in the world, the Russian fuel and energy balance is one of the most environmentally friendly (low-carbon): more than a third of electricity generation is accounted for by nuclear power, hydropower and other renewable energy sources; about half - for natural gas.
The energy infrastructure of the Russian Federation is a strategic resource for supporting, stimulating and ensuring economic growth [3.4]. At the same time, digital technologies, platform solutions, efficiency and safety should become the main factors for the development of the Russian energy industry in the future. New digital technologies make it possible to expand the production capabilities of the electric power industry, create new directions for the use of energy resources, increase the efficiency of their use, and optimize logistics [5]. In the face of increased competition, approaches to the regulation of energy markets are changing, the composition of used energy resources is diversifying, the main market participants are revising their strategies. The ongoing processes are extremely important for Russia, which ranks third in the world production of energy resources and rather strongly depends on the profitability of their exports. Against the background of the ongoing changes, the world energy market will have to find new equilibrium points, and Russia will have to correctly prioritize its further development [6]. An important factor in the development of the energy sector in Russia is the investment of companies, as well as the attraction of foreign investment for the implementation of projects related to the introduction of digital technologies $[7,8]$.

\section{Materials and methods}

The material for the work was data from Minenergo, PWC [9. 10], BRICS Energy Review [11], BRICS

*orresponding author: g.m.galeeeva@mail.ru 
Energy Research Platform, Energy development forecast world and Russia until 2040 (www.hse.ru), as well as data on the implementation of digital technologies in a company in the energy complex (PJSC Rosneft, PJSC Lukoil, PJSC Tatneft, PJSC Gazprom, PJSC Gazprom Neft, JSC SUEK, PJSC Rosseti, Federal Grid Company of the Unified Energy System, JSC Rotek).

To analyze the reasons, factors and prerequisites for the development of digitalization processes in the energy industry in Russia, such general scientific methods of cognition as analysis and synthesis, system analysis, structural analysis, comparison of the studied indicators, methods of grouping and generalization were used. An empirical analysis of the data was carried out on the basis of materials from the Russian statistical service, the Ministry of Energy of the Russian Federation, data posted on the official websites of companies in the energy complex of Russia.

The energy industry of the Russian Federation is characterized by the presence of a centralized management system and the preservation of mainly traditional sources of energy resources in the structure of the energy balance. In particular, guaranteeing suppliers are mainly represented on the energy market, tariff regulation is carried out, the interest of companies is focused on maintaining capacities and reducing losses. However, the prospects for the development of the industry are associated with such areas as increasing the profitability of the use of assets, including through the withdrawal of inefficient capacities, increasing labor productivity; investments in new directions of using energy resources (everything related to electric vehicles and energy storage devices); energy efficiency consulting; increasing competence in the field of digital technologies among specialists and personnel employed in the industry.

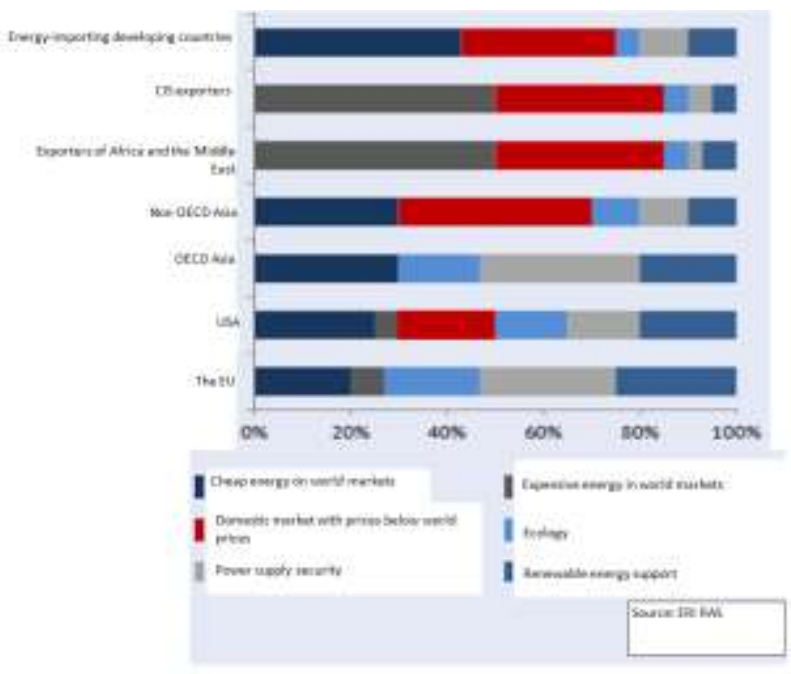

Fig. 1. Energy policy priorities of selected countries (Source: Forecast of energy development in the world and Russia until 2040 ERI RAS, AC 2013.105 p. [12]).

According to the Institute for Energy Research of the Russian Academy of Sciences, the priorities of the energy policy of individual countries include: cheap energy on world markets, the domestic market with prices below world prices, security, support for renewable energy sources, etc. [13] Energy security as the most important goal of energy policy is determined by the level of dependence countries' from external supplies and the likelihood of disruptions in them. As import dependence increases the course towards energy self-sufficiency, provided by own resources (including renewable) and production of national companies abroad. For exporters energy security reflects not only supplies to the domestic market, but also the stability of sales abroad due to the high dependence of the budgets of these countries on export earnings.

Achieving the goals and priorities of the energy policy is impossible without the use of digital technologies [14].

Digital technologies make it possible to optimize the management of complex energy systems. The competitiveness of large energy companies depends on the speed of digitalization of key business processes and the digital competence of personnel.

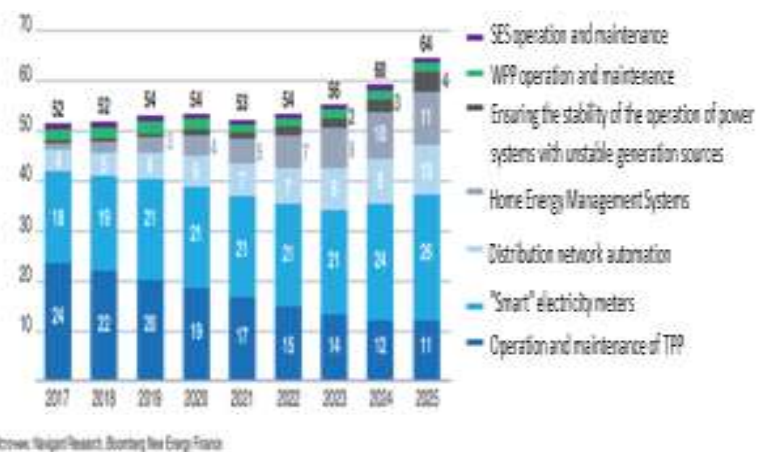

Fig. 2. The market of digital technologies in the energy sector, billion US dollars (Source: Navigant Research, Bloomberg New Energy Finance [15]).

As can be seen from Figure 2, the volume of the digital technologies market for the energy sector exceeds $\$ 50$ billion. At the same time, the largest market segments are digital technologies in the following directions:

- "smart" electricity meters;

- operation and maintenance of TPPs.

These segments in the digital energy market in aggregate amounted to about $\$ 40$ billion.

According to international forecasts by Bloomberg New Energy Finance, by 2025 the share of such segments as home energy management systems and distribution network automation will increase in the digital energy market. In total, the share of these segments will amount to $\$ 21$ billion by 2025 . In addition, by 2040 , investments in renewable energy will amount to $2 / 3$ of all investments in energy capacities and will amount to about 7.8 trillion US dollars.

Currently, the digital transformation of key business processes is observed in large companies in the fuel and energy complex of Russia. This is due, in our opinion, to the high technological potential, the availability of the necessary financial resources to invest in digitalization. 
In particular, PJSC Rosseti installed 2.9 million smart metering devices for electricity consumption. This was announced by a top manager of the company during a conference call. From July 1, 2020, the responsibility for the installation of metering devices was transferred to sales and network companies. Rosseti started the implementation of an intelligent accounting system in advance; currently, $15 \%$ of electricity supply facilities are equipped with smart meters. By the end of 2030, the company plans to commission 18.1 million meters. A set of measures for the installation of an intelligent system for collecting data on energy consumption is carried out within the framework of the Digital Transformation 2030 concept, approved by the Board of Directors of Rosseti in December 2018. The concept is aimed at reducing the company's costs, reducing electricity losses, increasing the reliability and quality of service.

Some information on the implementation of digital technologies by companies in the Russian fuel and energy complex is presented in Table 1 .

Table 1. The use of digital technologies by companies in the fuel and energy complex of Russia.

\begin{tabular}{|c|c|}
\hline Company name & $\begin{array}{c}\text { Introduction of digital } \\
\text { technologies }\end{array}$ \\
\hline PJSC Rosneft & $\begin{array}{l}\text { - Cloud computing model } \\
\text { • "Intelligent Field" } \\
\text { • "Smart Well" }\end{array}$ \\
\hline PJSC Lukoil & $\begin{array}{l}\text { - Modeling based on Big Data } \\
\text { - Center for spatial visualization } \\
\text { - "Intelligent Field" } \\
\text { - "Smart Well" }\end{array}$ \\
\hline PJSC Tatneft & $\begin{array}{l}\text { • Engineering Center } \\
\text { • "Smart Well" }\end{array}$ \\
\hline PJSC Gazprom & $\begin{array}{l}\text { • Engineering centers (VNIIGaz, } \\
\text { TyumenNIPIGiprogaz, etc.) } \\
\text { • "Intelligent Field" }\end{array}$ \\
\hline $\begin{array}{l}\text { PJSC Gazprom } \\
\text { Neft }\end{array}$ & $\begin{array}{l}\text { - Analysis of geological } \\
\text { information Geomate } \\
\text { - "Digital twin" of the refinery } \\
\text { - "Smart Well" } \\
\text { - Automated control center } \\
\text { - Implementation of the industrial } \\
\text { Internet }\end{array}$ \\
\hline JSC SUEK & $\begin{array}{l}\text { - "Intellectual career" } \\
\text { - Complex of intelligent systems } \\
\text { to ensure work safety }\end{array}$ \\
\hline PJSC Rosseti & $\begin{array}{l}\text { - Smart metering devices } \\
\text { - "Smart Grids" } \\
\text { - Digital substations }\end{array}$ \\
\hline $\begin{array}{l}\text { Federal Grid } \\
\text { Company of the } \\
\text { Unified Energy } \\
\text { System }\end{array}$ & $\begin{array}{l}\text { - Telecontrol equipment } \\
\text { substations }\end{array}$ \\
\hline JSC Rotek & $\begin{array}{l}- \text { Digital system of condition } \\
\text { prognostics } \\
\text { equipment for gas power plants }\end{array}$ \\
\hline
\end{tabular}

Energy companies have high potential for digitalization growth. This is evidenced by the practice of introducing digital technologies of large companies. The Rosseti Group has built a $110 \mathrm{kV}$ Soyuz digital switching point and $110 \mathrm{kV}$ transmission lines for technological connection of the new gas turbine power plant of Lukoil in the city of Berezniki, Perm Territory. This is stated in the group's telegram channel. The total cost of the work was about 200 million rubles, "- said in the message. Energy in excess of the volume for its own needs "Lukoil" will be sent to the network of the Bereznikovsko-Solikamsk power center. The power plant is part of the Parma Energy complex project, which is being implemented by Lukoil-Perm in cooperation with Rosseti Ural and domestic turbine manufacturers. Gas turbine units for the station were developed by UEC-Aviadvigatel. The power plant with a capacity of $16 \mathrm{MW}$ operates on associated petroleum gas, the group specified. Earlier, a similar power plant was built in the Kungur region at the Ilyichevsk oil field. Part of the generated electricity is sent through the new $35 \mathrm{kV}$ Yurman substation to the Rosseti Ural network.

Projects for the construction of digital regions of electrical networks (RES) are being implemented in the service regions of Rosseti Center, Rosseti Yantar and Rosseti North-West, where clusters have already been formed to develop Smart Grid technologies, as well as in the area of responsibility of Rosseti Center and Volga ".

Digital RES is an area of electrical grids with a high level of automation, providing "smart" electricity metering and remote online observability, as well as allowing to implement self-diagnostics and self-recovery functions. The Rosseti Group has developed a number of criteria for digital RES - the conditions under which the RES can be considered digital.

Work on the creation of digital RES is carried out in accordance with the concept of "Digital Transformation 2030", adopted in the "Rosseti" group. To date, four pilot projects have already been completed. A serious practical effect has been obtained. For example, if in 2016, before the start of the project in Mamonovsky Distribution Zone (Rosseti Yantar), the average time to restore power supply was 5.5 hours, now it is about 1 hour, and electricity losses have decreased by 2.5 times.

By the end of 2020, Rosseti Center and Rosseti Center and Volga Region planned to create 17 digital distribution zones. At Rosseti Yantar, 16 projects have been completed, that is, throughout the service area in the Kaliningrad region. Rosseti North-West will put another digital distribution zone into operation. The total number of digital distribution networks in the Rosseti group will grow to 38 , taking into account the four previously implemented "pilots".

The experimental innovative complex Digital Substation was launched at the Gazprom Neft Moscow Refinery. The implementation of the facility has become the next stage in the formation of a digital control system for energy facilities of the company's own Russian refineries. The future system will increase the efficiency, safety and reliability of the technological equipment of the Moscow Refinery. Earlier, the software and hardware complex "Digital Substation" began work at the Omsk Refinery.

Implementation of digital management models is one of the key areas of the Gazprom Neft refinery development program. The project provides for the digitalization of the operation of the equipment of the main step-down substation, which supplies the enterprise 
with electricity. A single information network will allow continuous online diagnostics of devices, which guarantees a stable power supply to the enterprise. The model will optimize the cabling network and reduce troubleshooting time. More than $70 \%$ of the digital substation equipment, including control and diagnostic systems, is of Russian origin.

In the future, the digital transformation of the industry will take place with the use of domestic developments. Institutions have been created and are functioning in Russia, whose developments can find practical application in the activities of energy companies. Currently, the following companies offer ready-made solutions in this area.

The Ruselectronics holding of the Rostec State Corporation has developed solutions for the digital transformation of the Russian energy industry. We are talking about intelligent electricity metering devices that allow you to read and store information in real time, notify about losses and monitor the quality of electricity. "Smart" devices are produced on the basis of domestic components, have mechanisms to protect against unauthorized access, including for the purpose of changing the meter readings.

Concern "Vega" has developed a drone for monitoring power lines. The copter is equipped with a camera, thermal imager and can operate in a fully automatic mode, independently collecting and transmitting data on the state of networks to operator services.

NPP "Contact" has developed high-voltage switches for electrical networks with a rated voltage of 35 and 10 $\mathrm{kV} \mathrm{AC}$. The equipment is intended for use at industrial enterprises, hazardous production facilities, including facilities of main pipeline transport.

NPP "Istok" named after Shokin" developed telecommunication equipment based on specialized software of domestic design and hardware platforms produced in the territory of the Russian Federation.

Digitalization of the power grid complex of Russia is an ambitious project of a national scale. Its implementation involves the introduction of advanced equipment at all power facilities, as well as the creation of a unified fully automated infrastructure management system. Issues related to the digital transformation of the Russian energy industry are strategically important for the country. Since the share of the fuel and energy complex in Russia's GDP is $23.6 \%$, and in exports $63.7 \%$.

Among the main problems and threats to further digital transformation of the energy industry in Russia, one should highlight:

1) a lack of investment required to create and maintain a new infrastructure and digital ecosystem, taking into account the high costs of software;

2) the risk of not achieving the declared effects;

3) an acute shortage of qualified personnel with digital competencies.

There are significant differences between utilities in the status of digital transformation: while some companies are embarking on digital transformation, others have already successfully implemented digital solutions in their current operations and are piloting digital solutions in the area of new business models. Companies implementing digital transformation programs are present in most regions around the world. Most utilities started their transformation 3-5 years ago.

\section{Results}

As a result of the study, it was revealed that investments and the introduction of digital technologies are of great importance for the development of the energy industry in Russia. The largest companies in the energy complex of Russia are already actively investing in digital technologies to ensure competitiveness. According to the Ministry of Energy of the Russian Federation, the key effects of digitalization of the industry should be:

1. Reducing the duration of power outages and the average frequency of technological disturbances (SAIDI / SAIFI) by $5 \%$ by 2024 .

2. Increasing the level of technical condition of production assets of the electric power industry for facilities by $5 \%$ by 2024 without increasing the cost of maintaining the technical condition.

3. Reduction by $20 \%$ of accidents at electric power facilities related to the technical condition of production assets by 2024 [15]

\section{Conclusion}

Thus, a prerequisite for changing the industry is the transformation of the largest companies, which consists in changing the operating model and business model. Digital transformation of energy involves:

1) unification, optimization, automation and flexible speed of processes;

2) the formation of organizational forms of support for digitalization (laboratories, incubators, etc.);

3) formation of plans for the development of competencies of employees;

4) formation of a digital infrastructure (servers, communication channels, equipment, sensors, etc.).

Digital technologies provide personnel with new tools (sensors, tablets, VR / AR, RPA, automation of maintenance processes, digital control of power facilities, development of platforms for interaction with customers, automation of business processes, the use of predictive analytics, optimization of inventory management processes, improving management efficiency repair teams, etc.), which allow you to reduce routine operations and focus on activities with added value for companies. An electricity meter and a heat metering control unit, connected to the network and capable of receiving and sending data, is part of an intelligent metering system (IMS) and a prerequisite for the implementation of a variety of digital technologies and solutions, both for energy companies and end consumers, as well as for increasing efficiency of energy companies using IMS analytics.

Digitalization covers several areas: digital media (social media, websites, marketing), digital processes, digital analytics, new digital business models. Many 
energy companies make the mistake of trying to implement too many ambitious digital strategies at the same time, and end up dissipating their financial and human resources over everything at once. It is far more effective to identify three to five top digitalization initiatives that are strategically important to protect and expand competitive advantage over start-ups and conventional energy companies. These so-called landmark projects, which can drive future digital initiatives, should span different business units and, ideally, different regions. They need support from the board of directors and constant oversight from management. Sufficient resources and staff should be allocated for their implementation.

\section{References}

1. BRICS Energy Research Platform, Energy Review of the BRICS Countries (October 2020)

2. New Energy Outlook (2016) Available at: https://about.bnef.com/blog/coal-and-gas-to-staycheap-but-renewables-still-win-race-on-costs/

3. Energy development forecast world and Russia until 2040 [Electronic resource] (2013) Available at:

https://www.hse.ru/data/2014/01/23/1325658082/ prognoz-2040.pdf

4. G.M. Galeeva, E.P. Fazlieva, R.K. Mingazova, R.I. Zinurova, Innovation as a part of strategic management and enterprise competitiveness of petrochemical cluster, Social Sciences and Interdisciplinary Behavior - Proceedings of the 4th International Congress on Interdisciplinary Behavior and Social Science, ICIBSOS, 213-216 (2015)

5. G.M. Galeeva, R.I. Zinurova, Technological modernization of industry, Social Sciences and Interdisciplinary Behavior: The 4th International Congress on Interdisciplinary Behavior and Social Science ICIBSoS, 217-221 (2015)

6. G. Mgaleeva, E.N. Zagladina, E.N Kadeeva, Z.K. Kadeeva, Model for assessing the influence of factors on a country's competitiveness in the global economy, Journal of Physics: Conference Series, 1391 (1), 012153 (2019)

7. G. Mgaleeva, Modeling the process of attracting foreign investment in the Russian economy, Journal of Physics: Conference Series, 1391 (1), 012154 (2019)

8. M.E. Ivanov, G.M. Galeeva, Diversification of sources of external financing the real economy in terms of institutional transformation, Journal of economics and economic education research, 17 (2), 415-422 (2016)

9. Energy Digital Operations Survey [Electronic resoruce] (2019) Available at: https://www.pwc.ru/ru/industries/power-andutilities/p\%26u_digital_operations_study_ru.pdf
10. Digital Operations Research in the Energy Sector [Electronic resoruce] (2019) Available at: https://www.pwc.ru/ru/industries/power-andutilities/p\%26u_digital_operations_study_ru.pdf

11. BRICS Energy Review [Electronic resoruce] (2020) Available at: https://minenergo.gov.ru/sites/default/files/07/20/ 18364/BRICS_Energy_Report_rus_10_11_2020_ F.pdf

12. Forecast of energy development in the world and Russia until 2040 ERI RAS, AC, 105 (2013)

13. R Ivanichkin,. P. Kashirin, $\mathrm{S}$ Sysoev, O. Shabunevich, U.O. James, Features of the process of digital transformation of the economy in Russia, Advances in Intelligent Systems and Computing, AISC, 1259, 187-197

14. Y. Gribanov, A. Shatrov, Modular digitalization of the energy sector, IOP Conference Series: Materials Science and Engineering, 497 (1), 012072 (2019)

15. Energy digitalization [Electronic resource] Available at: https://in.minenergo.gov.ru/energynet/docs. 